OPEN ACCESS

Edited by:

Patrik Andersson,

Harvard Medical School,

United States

Reviewed by:

Chandan Guha,

Albert Einstein College of Medicine,

United States

David Escors,

University College London,

United Kingdom

*Correspondence:

Heleen Vroman

h.vroman@erasmusmc.nl

Specialty section:

This article was submitted to

Cancer Immunity and Immunotherapy,

a section of the journal

Frontiers in Immunology

Received: 31 August 2018 Accepted: 09 November 2018 Published: 05 December 2018

Citation:

van Gulijk M, Dammeijer F, Aerts JGJV and Vroman H (2018) Combination Strategies to Optimize Efficacy of Dendritic Cell-Based Immunotherapy. Front. Immunol. 9:2759. doi: 10.3389/fimmu.2018.02759

\section{Combination Strategies to Optimize Efficacy of Dendritic Cell-Based Immunotherapy}

\author{
Mandy van Gulijk ${ }^{1,2}$, Floris Dammeijer ${ }^{1,2}$, Joachim G. J. V. Aerts ${ }^{1,2}$ and Heleen Vroman ${ }^{1,2 *}$ \\ ${ }^{1}$ Department of Pulmonary Medicine, Erasmus MC, Rotterdam, Netherlands, ${ }^{2}$ Erasmus Cancer Institute, Erasmus MC, \\ Rotterdam, Netherlands
}

Dendritic cells (DCs) are antigen-presenting cells (APCs) that are essential for the activation of immune responses. In various malignancies, these immunostimulatory properties are exploited by DC-therapy, aiming at the induction of effective anti-tumor immunity by vaccination with ex vivo antigen-loaded DCs. Depending on the type of DC-therapy used, long-term clinical efficacy upon DC-therapy remains restricted to a proportion of patients, likely due to lack of immunogenicity of tumor cells, presence of a stromal compartment, and the suppressive tumor microenvironment (TME), thereby leading to the development of resistance. In order to circumvent tumor-induced suppressive mechanisms and unleash the full potential of DC-therapy, considerable efforts have been made to combine DC-therapy with chemotherapy, radiotherapy or with checkpoint inhibitors. These combination strategies could enhance tumor immunogenicity, stimulate endogenous DCs following immunogenic cell death, improve infiltration of cytotoxic T lymphocytes (CTLS) or specifically deplete immunosuppressive cells in the TME, such as regulatory T-cells and myeloid-derived suppressor cells. In this review, different strategies of combining DC-therapy with immunomodulatory treatments will be discussed. These strategies and insights will improve and guide DCbased combination immunotherapies with the aim of further improving patient prognosis and care.

Keywords: DC-therapy, combination therapy, chemotherapy, radiotherapy, immune checkpoint inhibitors

\section{INTRODUCTION}

Dendritic cells (DCs) are the most potent antigen-presenting cells (APCs) and mediate a critical role in the interface between the innate and adaptive immune system. DCs can be subdivided in different subsets including conventional DCs (cDCs) and plasmacytoid DCs (pDCs) that arise in the bone marrow and reside in peripheral tissues in an immature state. In addition, monocytes are able to differentiate into monocyte-derived DCs (moDCs) upon inflammatory conditions (1-4). Activation and maturation of DCs are induced upon exposure to environmental stimuli including damage-associated molecular patterns (DAMPs) and pathogen-associated molecular patterns (PAMPs), leading to enhanced expression of co-stimulatory molecules, cytokine production, reduced phagocytosing capacity, and improved T- and B-cell activation $(5,6)$. DC-mediated T-cell 
activation is initiated by antigen presentation on major histocompatibility class (MHC) I and II and further guided by co-stimulation and secretion of cytokines (7-9). In addition to T-cell activation, DCs can activate natural killer (NK) cells by cell-cell contacts and secretion of pro-inflammatory cytokines such as type I interferons (IFNs) (10). However, in a tumor setting, DC functionality is often compromised as, for example, oncogenic mutations limit DC migration (11-14). In addition, factors secreted by cancer cells limit DC maturation by inducing overexpression of signal transducer and activation of transcription 3 (STAT-3) (15). This leads to insufficient antigen presentation, T-cell anergy and decreased T-cell proliferation, thereby restricting effective anti-tumor immunity (16-18).

Therefore, administering mature ex vivo-activated DCs loaded with tumor antigens may circumvent suppressive tumor-derived signals, thereby inducing effective anti-tumor immunity upon vaccination. For the past two decades, DCtherapy has shown to be safe, well-tolerated and capable of inducing anti-tumor immunity (19). However, response rates to DC-therapy are limited, with objective responses rarely exceeding $15 \%$ (20). Several mechanisms may contribute to the limited clinical efficacy besides suboptimal DC-therapy design, including downregulation of tumor-associated antigens (TAAs) and MHC molecules by tumor cells, restricted migration of DCs to lymph nodes (LN) and the inherent immune suppressive tumor microenvironment (TME) (21-26). The TME harbors a complex network of tumor tissue, stroma and immune cells including tumor-associated macrophages (TAMs), myeloid-derived suppressor cells (MDSCs), and regulatory T-cells (Tregs). These suppressive cells inhibit activation, proliferation and effector functions of infiltrating immune cells by the expression of co-inhibitory molecules and secretion of immunosuppressive cytokines (27-29). Conventional therapies, including chemotherapy and radiotherapy, or more recently developed immunotherapies such as immune checkpoint inhibitors are able to counteract the immunosuppressive environment of the tumor. Therefore, combining these therapies with DC-therapy could lead to synergistic effects and improve clinical responses. In this review, we will discuss current approaches of DC-therapy, promising combinations with chemotherapy, radiotherapy, and immune checkpoint inhibitors that are clinically applicable and future perspectives for novel combination therapies that can improve DC-therapy efficacy.

\section{CURRENT APPROACHES OF DC-THERAPY}

In order to obtain a sufficient number of DCs for administration, DCs are commonly generated from isolated CD $14^{+}$monocytes or from $\mathrm{CD}_{3}{ }^{+}$hematopoietic progenitors isolated from peripheral blood, bone marrow or cord blood $(3,5)$. Culturing purified $\mathrm{CD}^{+} 4^{+}$monocytes with granulocyte-monocyte derived growth factor (GM-CSF) and interleukin (IL) 4 will lead to differentiation into immature moDCs (30). Vaccination with these immature DCs loaded with tumor antigens characterizes first-generation DC-therapy and resulted in poor clinical results with a tumor regression of $3.3 \%$ (31). In second-generation DC-therapy, DCs are additionally matured by 'maturation cocktails' including Toll-like receptor ligands and cytokines which improved clinical results with objective response rates of $8-15 \%$ (31). Sipuleucel-T, the only US FDA approved DCtherapy for use in (prostate) cancer patients, can be positioned at the intersection between first- and second-generation DCtherapy as maturation is not achieved by maturation cocktails but rather by the fusion of GM-CSF to prostate antigen (32). In next generation DC-therapy, naturally-occurring DC (nDCs) subsets are employed as $\mathrm{nDCs}$ are superior over moDCs in terms of functionality and production costs and time. In addition, different DC subsets also induce different tumorspecific immune responses, as vaccination with murine $\mathrm{cDC} 1 \mathrm{~s}$ induced a prominent $\mathrm{CD}^{+}$T-cell driven anti-tumor immune response that was beneficial in tumors with abundant Tregs whereas cDC2s induced a Th17-mediated anti-tumor immune response that was advantageous in tumors with TAMs $(33,34)$. Clinical trials using $\mathrm{nDCs}$ have shown that the usage of $\mathrm{nDCs}$ is safe, feasible and associated with promising efficacy, which indicates that this should be further investigated $(35,36)$.

\section{Loading}

DCs can be loaded with different sources of tumor antigens, such as mRNA, peptides, proteins or whole tumor cell lysate $(5,37)$. While peptides bind directly to MHC molecules, proteins and tumor cells must be phagocytosed and processed before presentation on MHC molecules can occur. Furthermore, loading of DCs with tumor-associated peptides enables the induction of specific T-cell responses, thereby minimizing the risk on side-effects. However, for most tumor types, TAAs are still unidentified. Loading the DCs with tumor lysate circumvents the requirement of identified TAAs and additionally initiates a broad spectrum of immune responses that is not restricted to cytotoxic T lymphocyte (CTL) activation. This can improve DCtherapy efficacy as objective clinical responses observed upon treatment with DCs loaded with tumor lysate (8.3\%) are higher than treatment with DCs presenting defined antigens (3.6\%) in a meta-analysis of 173 trials (38).

\section{Route of Administration}

To induce effective anti-tumor immunity, migration of DCs to lymph nodes is essential. Therefore, various administration routes have been exploited (intradermally, intranodally, intravenously, subcutaneously, and intratumorally), although to date the superior route of administration is still not established. Also the percentages of DCs that migrate successfully toward the lymph nodes is limited, with up to $4 \%$ of injected DCs reaching the lymph node after intradermal injection and $0-56 \%$ reaching the lymph node after intranodal injection (26). The migratory capacity can be improved by preconditioning the injection site with a potent recall antigen, tetanus/dipteria toxoid, which improved overall survival (OS) and progression free survival (PFS) in glioblastoma patients (39). In addition to improving migratory capacity, researchers have also targeted apoptotic pathways by promoting Bcl-2 or inhibiting BAK/BAX signaling in DCs to increase the lifetime of DCs and thereby enhance 
bioavailability of the injected DCs, which resulted in improved activation of T-cells (40-43). However, despite these attempts to improve DC-therapy, combinatorial strategies are essential to prorogue suppressive mechanisms in the TME and to further potentiate the clinical efficacy of DC-therapy.

\section{COMBINATION THERAPIES TO ENHANCE DC-THERAPY EFFICACY}

\section{Combination With Chemotherapy}

Chemotherapeutics are traditionally designed to eradicate and eliminate malignant cells to lower tumor burden. However, more recent insights indicate that chemotherapy also has off-target immunological effects depending on the type of chemotherapy, such as immunogenic cell death (ICD) of tumor cells, thereby enabling the induction of anti-tumor immunity (44). ICD stimulates emission of DAMPs, including adenosine triphosphate (ATP), high mobility group box 1 (HMGB1), and calrecticulin (CALR), which initiates antigen uptake, maturation, activation, and recruitment of endogenous DCs in the tumor $(45,46)$. In addition, specific chemotherapeutics can directly deplete suppressive immune cells including Tregs and MDSCs (47-49). Due to the effects on tumor burden and the immunosuppressive TME, chemotherapeutics could have synergistic effects when combined with DC-therapy. For instance, tumor reduction by neo-adjuvant chemotherapy could improve DC-therapy, as DC-therapy is most effective in cases of low-tumor burden (31). In addition, depletion of immunosuppressive cells in the TME renders the TME more receptive for tumor-specific Tcell infiltration upon DC-therapy. Timing of chemotherapy administration may be crucial as potential synergistic effects of combination treatments depend on the interval and sequence of treatment administration (50). For instance, chemotherapy applied prior to DC-therapy with substantial intervals aims at tumor reduction whereas shorter intervals or concurrent combination therapy allow depletion of suppressive immune cells. In the following sections, combinations of well-studied chemotherapeutics with ex vivo antigen-loaded DCs will be discussed. A summary of the main characteristics of the studies is presented in Table $\mathbf{1}$.

\section{Cyclophosphamide}

Cyclophosphamide is an alkylating agent that has tumoricidal effects, thereby reducing tumor burden (72). In addition, cyclophosphamide initiates ICD and transient lymphoablation upon high doses, thereby resulting in depletion of suppressive immune cells and stimulation of anti-tumor T-cell responses. In contrast, low-dose cyclophosphamide improves tumor-specific immunity by Treg depletion (Figure 1) (47). In mesothelioma, melanoma and colon carcinoma murine models, administration of cyclophosphamide prior to DC-therapy prolonged survival compared to mice treated with monotherapy. This is likely caused by a cyclophosphamide-induced decrease in Tregs, and subsequent increase in T-cells, as observed in these studies $(51,52)$. Cyclophosphamide administration 3 days prior to DCtherapy was shown to induce T-cell responses to 3 melanoma gp100 antigen-derived peptides G154, G206-2M, and G280GV in 6 out of 7 melanoma patients post vaccination (55). A reduction in Tregs was also observed in mesothelioma patients treated with concurrent combination of cyclophosphamide and DC-therapy but remained unaffected in a study with melanoma patients $(56,57)$. These differences could be explained by differences in sampling time, as reduction in Tregs was evaluated after the first cyclophosphamide treatment in mesothelioma patients (56), whereas in melanoma patients, these levels were assessed after 4 and 6 cycles of DC-therapy (57). Combining DCtherapy with cyclophosphamide also improves clinical efficacy, as patients with ovarian cancer that received cyclophosphamide concurrent with DC-therapy and bevacizumab, a VEGF-a blocking antibody, exhibited significantly prolonged survival compared to patients without cyclophosphamide treatment (58). These results were associated with reduced TGF- $\beta$ levels, a cytokine that is abundantly produced by Tregs in ovarian cancer. Contradictory, combined DC-therapy with cyclophosphamide resulted in poor clinical responses in patients with metastatic renal cell carcinoma. However, as the DCs administered in this study were of allogeneic origin, the lack of clinical efficacy could be explained by the nature of the DCs administered (59). These results indicate that Treg depletion upon cyclophosphamide treatment is able to synergistically augment DC-therapy efficacy both in preclinical and clinical settings, depending on the tumor type and DCs applied.

\section{Temozolomide}

The alkylating agent temozolomide (TMZ) induces lymphoablation upon high doses whereas at low doses it primarily targets Tregs (Figure 1) (49). As this compound effectively crosses the blood-brain barrier, TMZ is mainly used to treat glioblastoma and melanoma, as the brain is a frequent metastatic site for melanoma $(73,74)$. In patients with advanced melanoma, administration of one TMZ cycle prior to each DC-therapy decreased circulating Tregs with 60.5\% (60). Simultaneous administration of TMZ and DC/glioma cell fusions in recurrent and newly-diagnosed glioblastoma patients resulted in WT-1, gp100, and MAGE-A3-specific CTLs upon vaccination. In the newly-diagnosed patients, PFS and OS were improved compared to an international trial of TMZ monotherapy (61). However, in recurrent glioblastoma patients, where DC-therapy was followed by TMZ administration, combined treatment failed to improve 6-month PFS compared to a reference group with TMZ monotherapy (62). This could be due to reduced CTL numbers caused by TMZ-induced lymphoablation, thereby counteracting the effects of DC-therapy, as shown by a recent study (63). Interestingly, this study also illustrated that, in contrast to CTL numbers, NK cells in peripheral blood remained constant after concurrent combinations with TMZ. However, whether the effects observed on NK cells were associated with depletion of Tregs remains elusive. Furthermore, this indicates that TMZ administration before or during DC-therapy could enhance DC-therapy efficacy, whereas DC-therapy followed by TMZ may exert negative effects on DC-induced anti-tumor immunity. 

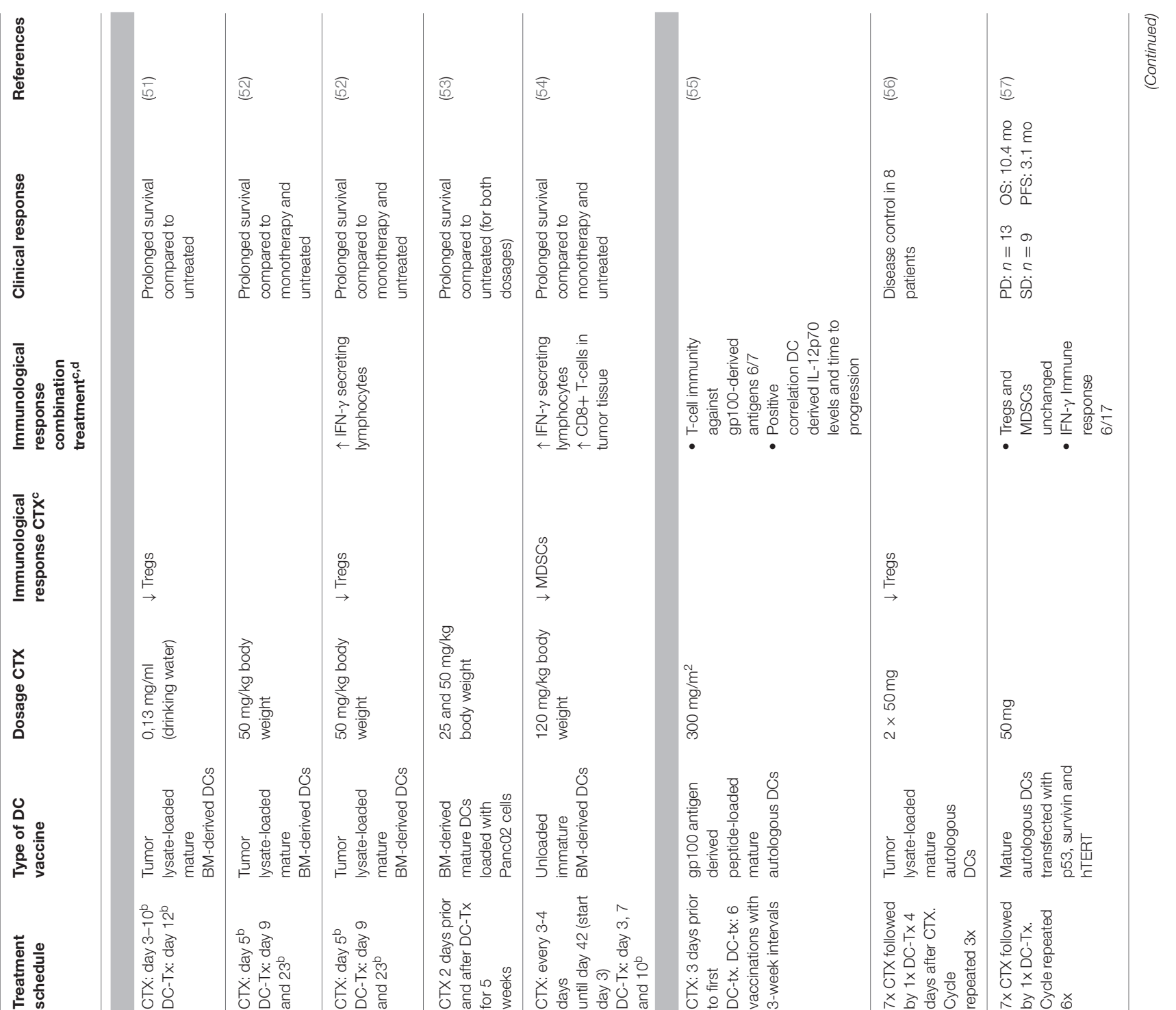

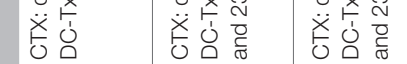

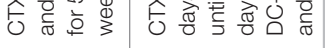
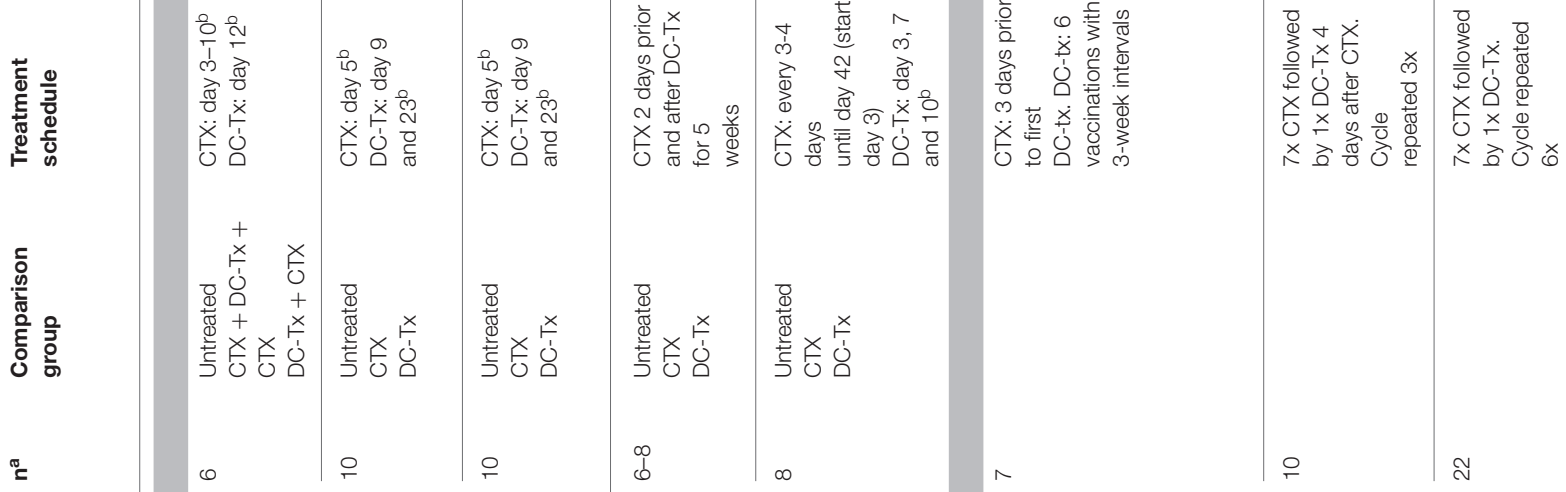

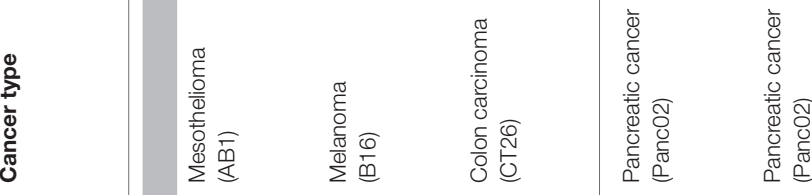
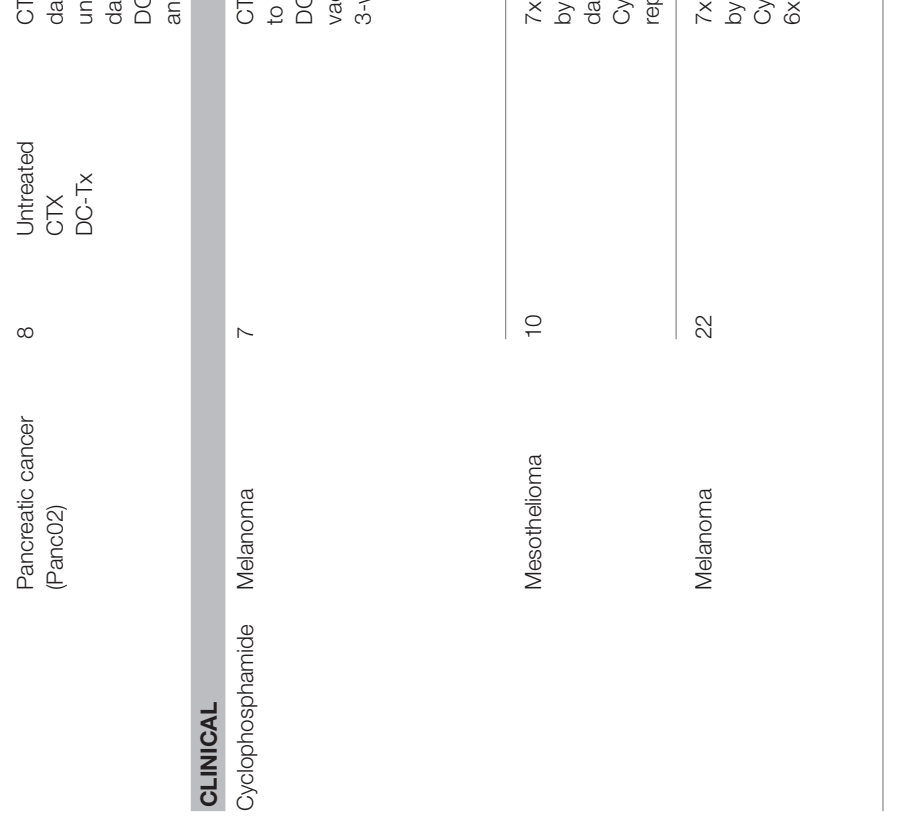


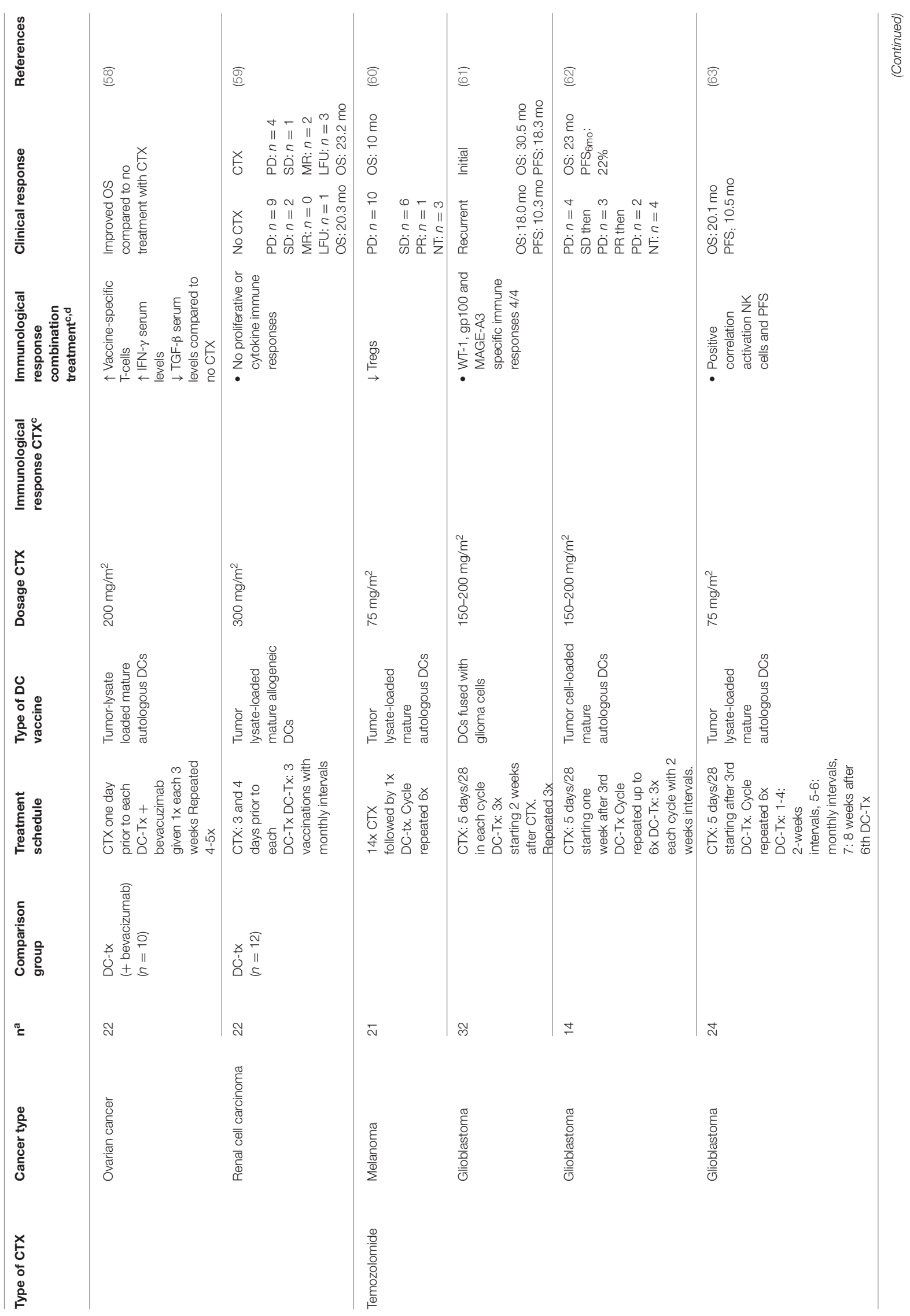




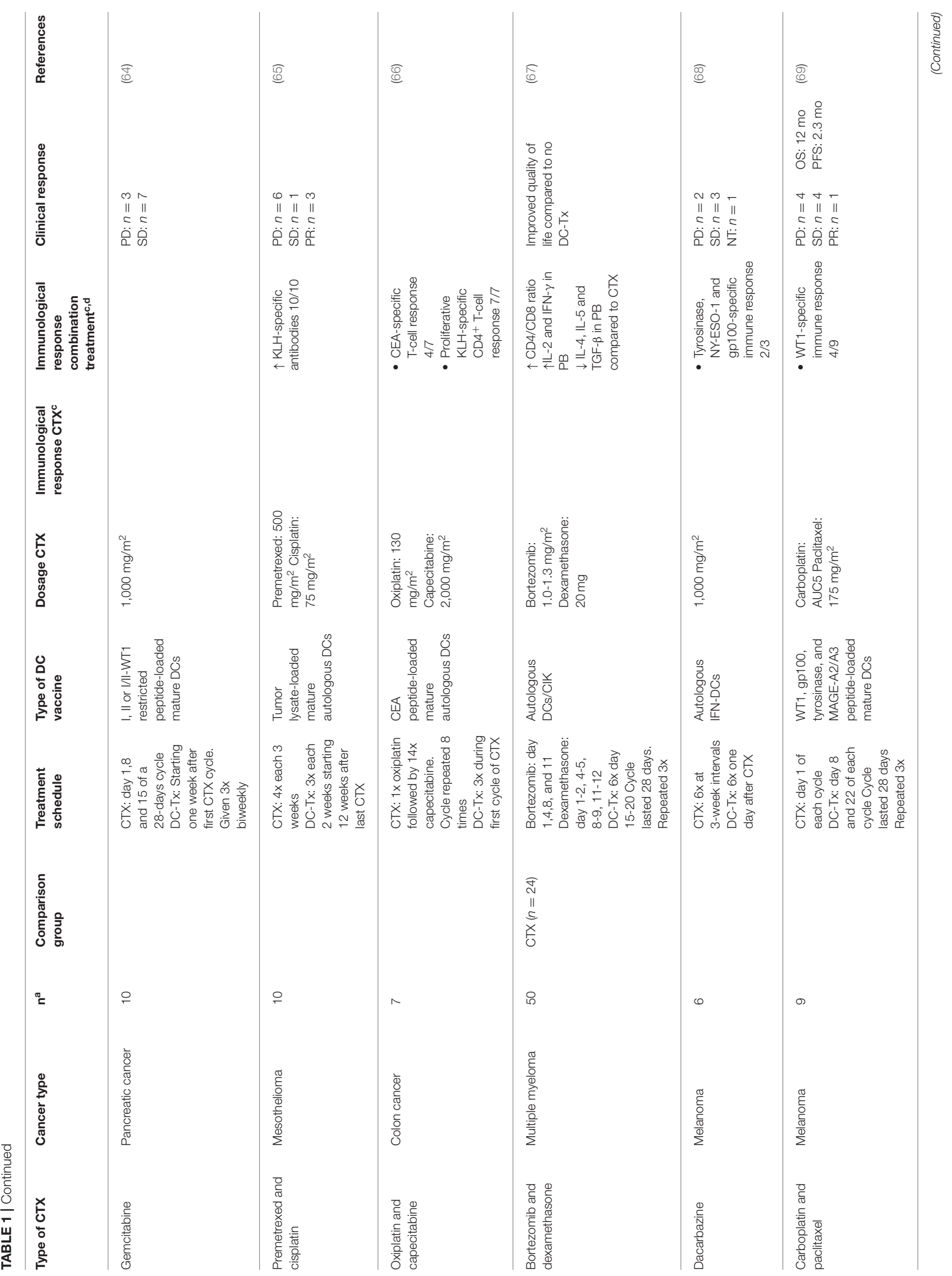




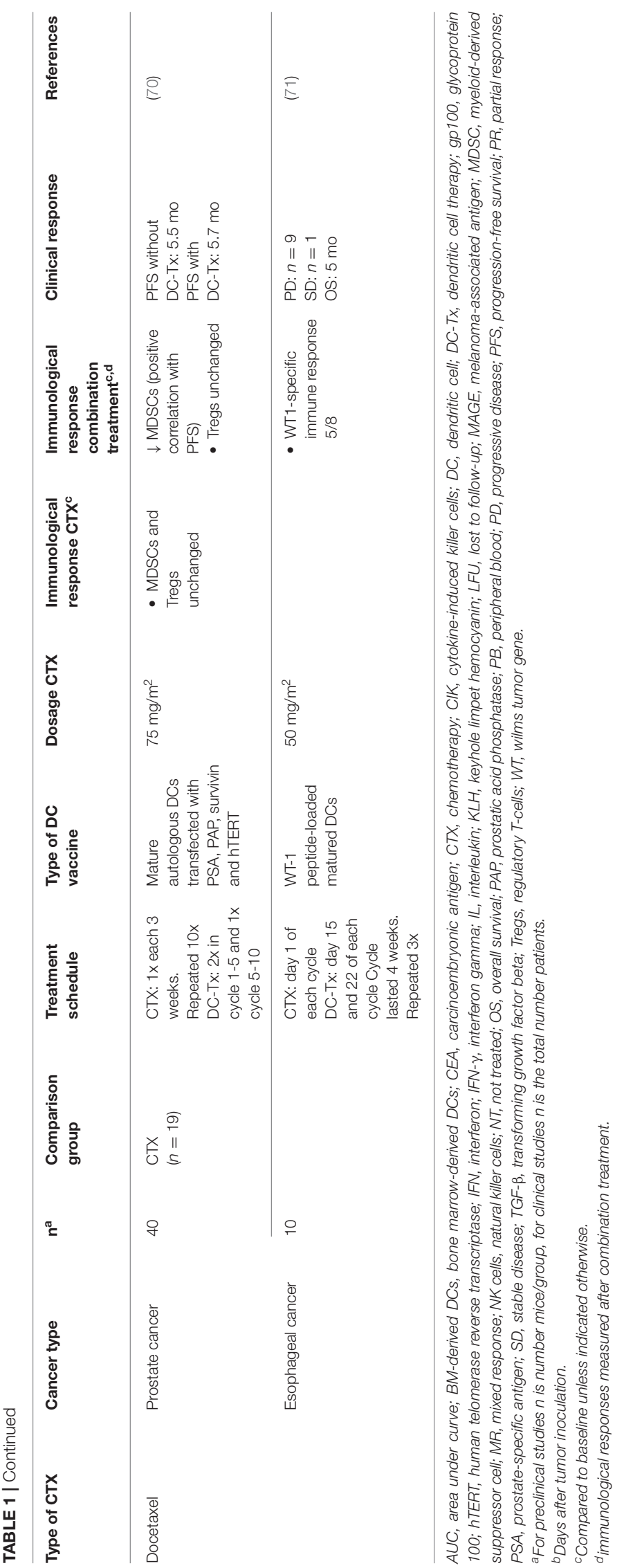

\section{Gemcitabine}

Gemcitabine is able to improve anti-tumor immunity by depletion of MDSCs and Tregs (Figure 1) $(47,48,75)$. Treatment of mice bearing pancreatic tumors with gemcitabine 2 days before and after DC-therapy prolonged survival compared to untreated mice, which was not observed for both monotherapies (53). Concurrent treatment of DC-therapy and gemcitabine in a murine pancreatic model delayed tumor growth and prolonged survival compared to both monotherapies. This could be dependent on MDSC numbers, as MDSC numbers were significantly reduced in spleens and tumors of mice treated with gemcitabine (54). However, in pancreatic cancer patients, despite decreased PD- ${ }^{+}$CTL numbers in responders, the concurrent combination did not result in decreased MDSC and Treg numbers in responders vs. non-responders (64). These results indicate that gemcitabine may enhance DC-therapy efficacy, however the mechanism of action warrants further investigation.

\section{Combination With Other Chemotherapies}

With the aim to reduce tumor burden, Hegmans et al. treated mesothelioma patients with premetrexed and cisplatin 12 weeks prior to DC-therapy, which resulted in immunological responses in all patients against keyhole limpet hemocyanin (KLH), a protein used to assess T-cell responses initiated by DC-therapy (65). As this trial has no control arm no conclusions on synergy can be made. Co-administration of oxiplatin, capecitabine and DC-therapy in colon cancer patients induced proliferation of KLH-specific CD4 ${ }^{+}$T-cells in all patients as well (66). An effect on $\mathrm{CD}^{+}{ }^{+} \mathrm{T}$-cells was also observed in multiple myeloma patients wherein treatment with DCs and cytokine-induced killer cells (CIK) combined with bortezomib and dexamethasone improved $\mathrm{CD}^{+} / \mathrm{CD}^{+} \mathrm{T}$-cell ratios compared to baseline and treatment with chemotherapy alone (67). Specific anti-tumor immunity with CTLs directed against gp100, tyrosine and NY-ESO was induced in $67 \%$ of the patients with advanced melanoma treated with the combination of DC-therapy and dacarbazine (68). In addition, in $44 \%$ of the patients with stage IV melanoma, a specific immune response against WT1 was induced upon treatment with DC-therapy and carboplatin and paclitaxel (69). However, combination with docetaxel failed to improve clinical responses in patients with esophageal cancer and did not result in improved PFS in patients with prostate cancer compared to docetaxel monotherapy $(70,71)$. These results indicate that combined treatment with chemotherapy and DC-therapy is feasible and safe, however further research should be conducted providing insight into the potential synergistical effects.

\section{Combination With Radiotherapy}

Ever since radiotherapy was found to affect non-radiated tumor lesions in a process called the abscopal effect, the immunomodulatory effects of this therapy have been more thoroughly appreciated. As radiotherapy induces ICD, one primary effect is the release of DAMPs and tumor-derived antigens, thereby initiating the activation and migration of DCs to the LN where DCs subsequently cross-present these antigens to T-cells and induce systemic anti-tumor immune 


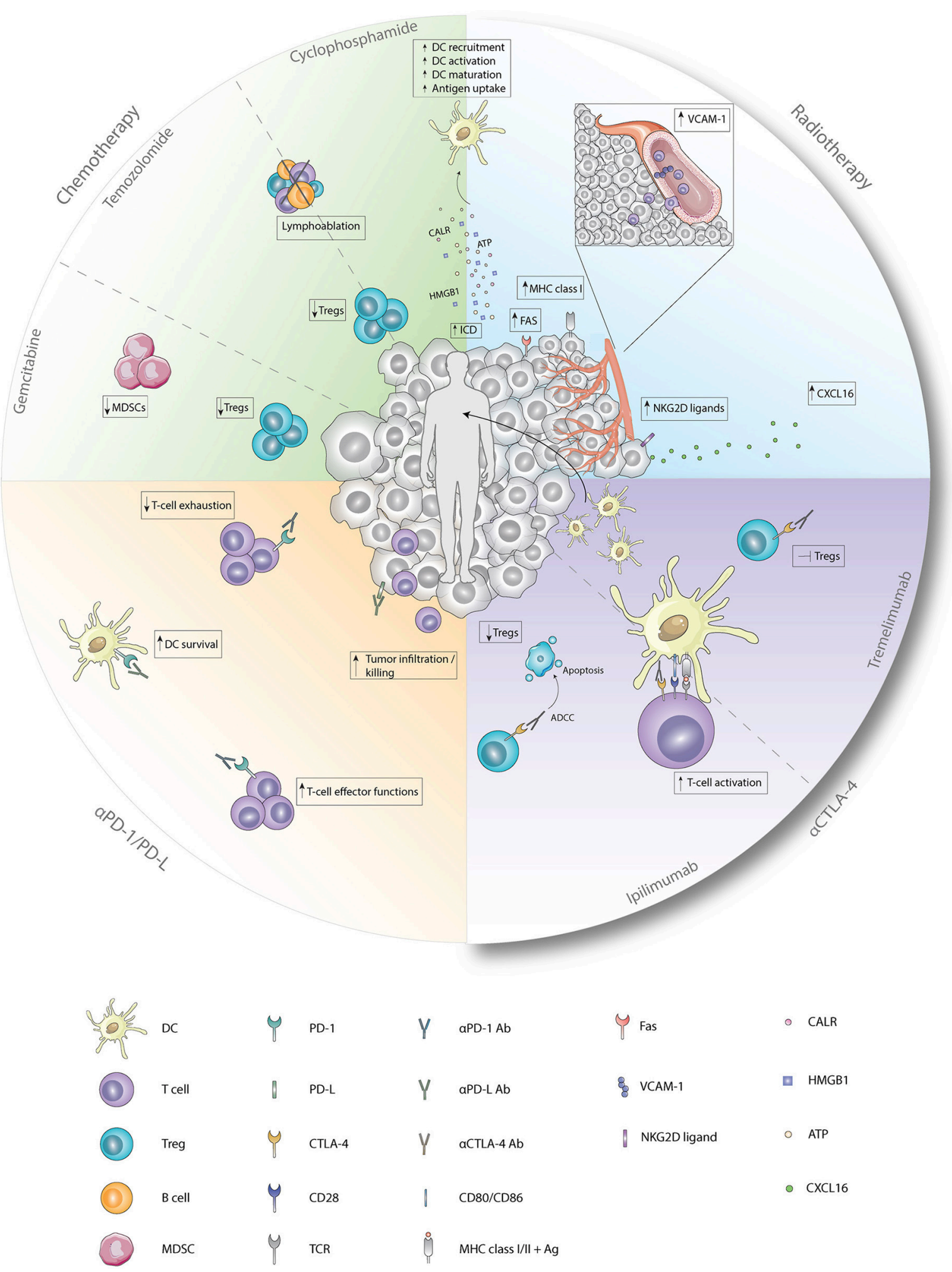

FIGURE 1 | Immunological effects of chemotherapy, radiotherapy, and checkpoint inhibitors. Cyclophosphamide induces ICD which enhances the recruitment, activation, maturation, and antigen uptake by DCs. In addition, cyclophosphamide and temozolomide deplete Tregs and induce lymphoablation upon treatment with low-dose or high-dose, respectively. Immunological functions of gemcitabine entail depletion of Tregs and MDSCs. Radiotherapy induces, besides ICD, enhanced expression of FAS, MHC class I, and NKG2D ligands on tumor cells and enhanced expression of VCAM-1 on endothelial cells. Furthermore, secretion of CXCL16 by tumor cells is increased after radiotherapy. Antagonistic CTLA-4 antibodies enhance T-cell activation by the preventing the binding of CD28 with CD80/86. Ipilimumab (Continued) 
FIGURE 1 | depletes Tregs by ADCC whereas tremelimumab inhibits functions of Tregs upon binding. Anti-PD1 antagonistic antibodies enhance T-cell effector functions while preventing exhaustion of T-cells. Blockade of PD-1 on DCs improves survival while blockade of PD-L on tumor cells results in improved tumor-cell infiltration and killing. Ab, antibody; Ag, antigen; ATP, adenosine triphosphate; CALR, calreticulin; CTLA-4, cytotoxic T-lymphocyte-associated antigen; CXCL16, chemokine ligand 16; DC, dendritic cell; Fas, first apoptosis signal; HMGB1, high mobility group box 1; MDSC, myeloid-derived suppressor cell; MHC class I/II, major histocompatibility complex class I/II; NKG2D ligand, natural killer group 2 member D; PD-1, programmed death 1; PD-L, programmed death ligand; TCR, T-cell receptor; Treg, regulatory T cell; VCAM-1, vascular endothelial cell adhesion protein 1.

responses (Figure 1) (76-80). The induction of systemic antitumor immunity was indeed observed when radiotherapy was combined with GM-CSF as it generated abscopal effects in some patients (81). In addition, the combination with Flt3 ligand in a Lewis lung carcinoma murine model reduced metastases and prolonged survival (82). However, in settings of compromised DC functionality, intratumoral injection of exogenously-prepared unloaded DCs followed by radiotherapy could be advantageous. Induction of systemic immunity was observed in a squamous-cell carcinoma murine model, as combining radiotherapy with intratumoral DC administration increased the presence of CTLs in the tumor-draining LN (TDLN) compared to DC-monotherapy (83). In addition, reduced tumor burden and prolonged survival were observed compared to monotherapy in multiple preclinical models (8488). In clinical trials with patients suffering from hepatocellular carcinoma and high-risk sarcoma, combining intratumoral injection of unloaded DCs with radiotherapy induced tumorspecific immunity in 70 and $52.9 \%$ of the cases, respectively (89, 90). In addition to induction of synergistic effects when combined with unloaded DCs, radiotherapy may also improve efficacy when combined with loaded DCs as it transforms irradiated tissue into an immunogenic niche by enhancing the expression of vascular endothelial cell adhesion protein 1 (VCAM-1) on endothelial cells, FAS, MHCI and natural killer group 2D (NKG2D) on tumor cells and increasing CXCL16 secretion, thereby promoting homing, infiltration and tumor killing by DCinduced lymphocytes (Figure 1) (91-96). In patients with stage I esophageal cancer, 1- and 2-year survival were significantly improved upon treatment with loaded DCs and radiotherapy as compared to radiotherapy alone. Addition of CIK to this combination failed to improve survival in patients with stage III/IV non-small-cell lung cancer $(97,98)$. These results indicate that combinatorial treatment has synergistic effects, but these depend on tumor type and stage, as improved efficacy is most prominent at early tumor stages.

\section{Combination With Immune Checkpoint Inhibitors}

In cancer, tumor cells and immune cells often overexpress co-inhibitory molecules, such as PD-1/PD-L1 and CTLA-4, which suppress anti-tumor immunity. Checkpoint inhibitors targeting these co-inhibitory molecules improve existing anti-tumor immunity when administered as monotherapy (99, 100). Additionally, combinations with DC-therapy may result in synergistic effects as expression of these coinhibitory molecules could also limit durable DC-therapy effects by inhibiting DC-therapy induced T-cells as well as DCs directly.

\section{PD-1/PD-L Blocking Antibodies}

The PD-1/PD-L-axis exerts negative effects on TME-infiltrating immune cells by inhibiting T-cell effector functions, NK cells and inducing T-cell exhaustion (101-104). Additionally, PDL1 expression on tumor cells also directly inhibits IFN- $\gamma$ mediated cytotoxicity by a STAT3/caspase 7 dependent pathway (105). Therapeutically targeting PD-1/PD-L1 could therefore render the TME more receptive for lymphocyte infiltration and sensitize tumor cells for cytotoxicity that could act synergistically upon combination with DC-therapy (Figure 1). Combining DCtherapy with PD-1 blockade reduced Tregs, induced IFN- $\gamma$ secretion, while secretion of IL-10 by CD $4^{+}$T-cells was decreased. In addition, cytotoxicity of CTLs improved when PD-1 was inhibited in a co-culture of tumor cells and Tcells isolated from mice treated with $\mathrm{DC} /$ myeloma fusions (106). In vivo investigation of DC-therapy combined with PD1 blockade reduced tumor volume of mice with melanoma (107) and prolonged survival in murine models for glioblastoma (108) compared to monotherapy. These beneficial effects on anti-tumor immunity were also observed in a breast cancer murine model upon combinations with anti-PD-L1 antibodies (109). Additionally, this study investigated the combination of specific blockade of PD-L1 on DCs by in vitro incubation with antagonistic monoclonal antibodies (109).

PD-L1/2 are both expressed on DCs and are associated with suppression of effector CTLs and $\mathrm{CD}^{+}{ }^{+} \mathrm{T}$-cells and induction of Treg expansion (110-117). Conversely, the expression of PD1 on DCs negatively affects DC survival (118). This indicates that blockade of PD-1 or PD-L1 on DCs could enhance antitumor immunity in vivo via multiple ways. PD-L1 blockade on DCs improved maturation and proliferation of DCs during culture, inhibited tumor outgrowth and prolonged survival compared to mice treated with DCs on which PD-L1 was not blocked (109). These results underline the importance of PD-L1 expression on DCs in inhibiting anti-tumor immunity. Therefore, efforts are undertaken to establish DC-specific PDL1 blockade, primarily by different RNA introducing techniques, such as small interference RNA (siRNA) or short hairpin RNA (shRNA). Preclinical data indicate that PD-L1 can effectively be silenced using these approaches without affecting viability, maturation or costimulatory molecule expression. In addition, silencing PD-L1 or PD-L2 specifically on DCs enhanced proliferation of tumor-specific CTLs and CD4 ${ }^{+} \mathrm{T}$ cells, augmented production of IFN- $\gamma$, tumor-necrosis factor alpha (TNF $\alpha)$, IL-2, IL-5, and IL-12 and promoted cytolysis of tumor cells in vitro (119-123). These promising data provide incentive to further investigate the combination of systemic PD-(L)1 blockade with DC-therapy and PD-L1 blockade on DCs. 


\section{CTLA-4}

The antagonistic antibodies ipilimumab and tremelimumab are designed to target CTLA-4, an inhibitory pathway that inhibits activation of naïve T-cells by preventing the binding of CD28 on T-cells to CD80/CD86 on APCs, a mechanism widely exploited by Tregs $(124,125)$. In various murine models, ipilimumab was shown to induce antibody-dependent cell-mediated cytotoxicity (ADCC), thereby facilitating Treg depletion while tremelimumab inhibits effector functions of Tregs (Figure 1) (126, 127). However, recent clinical data question the Treg-depleting capacity of ipilimumab, as treatment with ipilimumab did not deplete Tregs in the TME of patients with melanoma, prostate cancer and bladder cancer (128). In a retrospective study with stage III melanoma patients that progressed after DC-therapy, administration of ipilimumab induced tumor-specific T-cell responses in $72 \%$ of the cases although this was not associated with improved OS (129). Clinical and CTL responses were also not associated in a clinical trial with 16 melanoma patients treated with MART-1 peptide loaded DCs and tremelimumab (130). However, most promising clinical results were obtained by a recent study, in which the overall response rate reached $38 \%$ in advanced melanoma patients. These patients were treated with ipilimumab combined with DCs electroporated with CD40L, CD70, and constitutively activated TLR-4 encoding mRNA and one of 4 melanoma-associated antigens (MAGE-A3, MAGE-C2, tyrosinase, or gp100) fused to an HLA-class II targeting signal (131). This indicates that combining DC-therapy with CTLA-4 targeting agents could lead to synergistic effects.

\section{Combination With Other Immunomodulating Therapies}

Recently, also other immunomodulatory therapies were approved that enable depletion of specific immunosuppressive cell types, such as macrophages that are depleted upon antibody or tyrosine kinase inhibition of the M-CSF-receptor. In line, we have previously combined DC-therapy with M-CSFR inhibitor treatment in murine tumor models and found improved survival compared to DC-monotherapy. In addition, numbers, proliferation and exhaustion state of CTLs were improved (132). Similar results were obtained when combining DC-therapy with a CD40-agonistic antibody, capable of converting macrophages to a proinflammatory phenotype, and further stimulating the CD $40^{+}$DCs (133). Besides macrophages, selective depletion of Tregs could enhance anti-tumor immunity. Results in a preclinical melanoma mouse model showed that depletion of Tregs using anti-CD25 antibodies prior to DC-therapy elicits

\section{REFERENCES}

1. Guilliams M, Dutertre CA, Scott CL, McGovern N, Sichien D, Chakarov S, et al. Unsupervised high-dimensional analysis aligns dendritic cells across tissues and species. Immunity (2016) 45:669-84. doi: 10.1016/j.immuni.2016.08.015

2. Guilliams M, Ginhoux F, Jakubzick C, Naik SH, Onai N, Schraml BU, et al. Dendritic cells, monocytes and macrophages: a unified nomenclature based on ontogeny. Nat Rev Immunol. (2014) 14:571-8. doi: 10.1038/nri3712

3. Sabado RL, Balan S, Bhardwaj N. Dendritic cell-based immunotherapy. Cell Res. (2017) 27:74-95. doi: 10.1038/cr.2016.157 long-lasting anti-tumor immunity, as most mice remained tumor-free after tumor rechallenge (134). Further investigation into these combinations in different (pre)clinical models could lead to promising novel combination strategies.

\section{FUTURE PERSPECTIVES}

Despite the clinical success of DC-therapy, clinical efficacy remains limited to a proportion of patients and integration of combinatorial approaches are therefore warranted to improve efficacy. Timing of these combinatorial approaches should be carefully considered as this will affect the potential synergistic mode of action. In addition, determining optimal combination therapies likely depends on multiple factors including patient's condition, tumor type, stage and composition of the TME. Therefore, characterization of tumor cells and immune cells present in the TME or peripheral blood of individual patients will help to select immunotherapies that most likely will work synergistically with DC-therapy. For example, treatment of tumors enriched with Tregs should entail combinations with Treg-depleting chemotherapeutics, whereas DC-therapy should be combined with PD-L1 antagonistic antibodies in tumors with high PD-L1 expression. Furthermore, careful characterization of the TME, and peripheral blood could provide novel insights for combination strategies.

\section{CONCLUSION}

Although combinations with DC-therapy have demonstrated beneficial effects contributing to anti-tumor immunity, the potential for further improvement remains. A major focus should be on the careful characterization of tumor and peripheral blood of each individual patient as this will be needed to tailor treatments and enhance efficacy on a personalized level. In addition, more controlled clinical trials should be executed to directly compare efficacy with monotherapy. Timing of treatment administration should be taken into consideration in these studies as it could affect the efficacy of combination therapies.

\section{AUTHOR CONTRIBUTIONS}

MvG and HV wrote the manuscript and generated the figure and table. FD and JA contributed to the revisions of the manuscript. All authors approved the manuscript for publication.

4. Patel VI, Metcalf JP. Identification and characterization of human dendritic cell subsets in the steady state: a review of our current knowledge. J Investig Med. (2016) 64:833-47. doi: 10.1136/jim-2016-0 00072

5. Constantino J, Gomes C, Falcao A, Neves BM, Cruz MT. Dendritic cell-based immunotherapy: a basic review and recent advances. Immunol Res. (2017) 65:798-810. doi: 10.1007/s12026-017-8 931-1

6. Hopp AK, Rupp A, Lukacs-Kornek V, Self-antigen presentation by dendritic cells in autoimmunity. Front Immunol. (2014) 5:55. doi: 10.3389/fimmu.2014.00055 
7. Steinman RM. The dendritic cell system and its role in immunogenicity. Аnnu Rev Immunol. (1991) 9:271-296. doi: 10.1146/annurev.iy.09.040191. 001415

8. Gardner A, Ruffell B. Dendritic cells and cancer immunity. Trends Immunol. (2016) 37:855-65. doi: 10.1016/j.it.2016.09.006

9. Bol KF, Schreibelt G, Gerritsen WR, de Vries IJ, Figdor CG. Dendritic cellbased immunotherapy: state of the art and beyond. Clin Cancer Res. (2016) 22:1897-906. doi: 10.1158/1078-0432.CCR-15-1399

10. Münz C, Dao T, Ferlazzo G, de Cos MA, Goodman K, Young JW. Mature myeloid dendritic cell subsets have distinct roles for activation and viability of circulating human natural killer cells. Blood (2005) 105:266-73. doi: 10.1182/blood-2004-06-2492

11. Wellenstein MD, de Visser KE. Cancer-cell-intrinsic mechanisms shaping the tumor immune landscape. Immunity (2018) 48:399-416. doi: 10.1016/j.immuni.2018.03.004

12. Peng W, Chen JQ, Liu C, Malu S, Creasy C, Tetzlaff MT, et al. Loss of PTEN promotes resistance to $\mathrm{T}$ cell-mediated immunotherapy. Cancer Discov. (2016) 6:202-16. doi: 10.1158/2159-8290.CD-15-0283

13. Spranger S, Bao R, Gajewski TF. Melanoma-intrinsic beta-catenin signalling prevents anti-tumour immunity. Nature (2015) 523:231-5. doi: 10.1038/nature14404

14. Spranger S, Luke JJ, Bao R, Zha Y, Hernandez KM, Li Y, et al. Density of immunogenic antigens does not explain the presence or absence of the T-cellinflamed tumor microenvironment in melanoma. Proc Natl Acad Sci USA. (2016) 113:E7759-68. doi: 10.1073/pnas.1609376113

15. Nefedova $Y$, Huang $M$, Kusmartsev S, Bhattacharya R, Cheng $P$, Salup R, et al. Hyperactivation of STAT3 is involved in abnormal differentiation of dendritic cells in cancer. J Immunol. (2004) 172:464-74. doi: 10.4049/jimmunol.172.1.464

16. Tang M, Diao J, Cattral MS. Molecular mechanisms involved in dendritic cell dysfunction in cancer. Cell Mol Life Sci. (2017)74:761-76. doi: $10.1007 / \mathrm{s} 00018-016-2317-8$

17. Pinzon-Charry A, Maxwell T, Lopez JA. Dendritic cell dysfunction in cancer: a mechanism for immunosuppression. Immunol Cell Biol. (2005) 83:451-61. doi: 10.1111/j.1440-1711.2005.01371.x

18. Chen DS. Mellman I. Oncology meets immunology: the cancer-immunity cycle. Immunity (2013) 39:1-10. doi: 10.1016/j.immuni.2013.07.012

19. Constantino J, Gomes C, Falcao A, Cruz MT, Neves BM. Antitumor dendritic cell-based vaccines: lessons from 20 years of clinical trials and future perspectives. Transl Res. (2016) 168:74-95. doi: 10.1016/j.trsl.2015.07.008

20. Anguille S, Smits EL, Lion E, van Tendeloo VF, Berneman ZN. Clinical use of dendritic cells for cancer therapy. Lancet Oncol. (2014) 15:e257-267. doi: 10.1016/S1470-2045(13)70585-0

21. Ghirelli C, Hagemann T. Targeting immunosuppression for cancer therapy. J Clin Invest. (2013) 123:2355-7. doi: 10.1172/JCI69999

22. Blankenstein T, Coulie PG, Gilboa E, Jaffee EM. The determinants of tumour immunogenicity. Nat Rev Cancer (2012) 12:307-13. doi: 10.1038/nrc3246

23. Vasaturo A, Di Blasio S, Peeters DG, de Koning CC, de Vries JM, Figdor CG, et al. Clinical implications of co-inhibitory molecule expression in the tumor microenvironment for de vaccination: a game of stop and go. Front Immunol. (2013) 4:417. doi: 10.3389/fimmu.2013.00417

24. Devaud C, John LB, Westwood JA, Darcy PK, Kershaw MH. Immune modulation of the tumor microenvironment for enhancing cancer immunotherapy. Oncoimmunology (2013) 2:e25961. doi: 10.4161/onci. 25961

25. Seyfizadeh N, Muthuswamy R, Mitchell DA, Nierkens S, Seyfizadeh N. Migration of dendritic cells to the lymph nodes and its enhancement to drive anti-tumor responses. Crit Rev Oncol Hematol. (2016) 107:100-10. doi: 10.1016/j.critrevonc.2016.09.002

26. Verdijk P, Aarntzen EH, Lesterhuis WJ, Boullart AC, Kok E, van Rossum MM, et al. Limited amounts of dendritic cells migrate into the T-cell area of lymph nodes but have high immune activating potential in melanoma patients. Clin Cancer Res. (2009) 15:2531-40. doi: 10.1158/1078-0432.CCR-08-2729

27. Mantovani A, Marchesi F, Malesci A, Laghi L, Allavena P. Tumourassociated macrophages as treatment targets in oncology. Nat Rev Clin Oncol. (2017) 14:399-416. doi: 10.1038/nrclinonc.201 6.217
28. Kumar V, Patel S, Tcyganov E, Gabrilovich DI. The nature of myeloid-derived suppressor cells in the tumor microenvironment. Trends Immunol. (2016) 37:208-20. doi: 10.1016/j.it.2016.01.004

29. Tanaka A, Sakaguchi S. Regulatory T cells in cancer immunotherapy. Cell Res. (2017) 27:109-18. doi: 10.1038/cr.2016.151

30. Sallusto F, Lanzavecchia A. Efficient presentation of soluble antigen by cultured human dendritic cells is maintained by granulocyte/macrophage colony-stimulating factor plus interleukin 4 and downregulated by tumor necrosis factor alpha. J Exp Med. (1994) 179:1109-18. doi: 10.1084/jem.179.4.1109

31. Garg AD, Coulie PG, Van den Eynde BJ, Agostinis, P. Integrating nextgeneration dendritic cell vaccines into the current cancer immunotherapy landscape. Trends Immunol. (2017) 38:577-93. doi: 10.1016/j.it.2017. 05.006

32. Kantoff PW, Higano CS, Shore ND, Berger ER, Small EJ, Penson DF, et al. Sipuleucel-T immunotherapy for castration-resistant prostate cancer. $N$ Engl J Med. (2010) 363:411-22. doi: 10.1056/NEJMoa1001294

33. Laoui D, Keirsse J, Morias Y, Van Overmeire E, Geeraerts X, Elkrim Y, et al. The tumour microenvironment harbours ontogenically distinct dendritic cell populations with opposing effects on tumour immunity. Nat Commun. (2016) 7:13720. doi: 10.1038/ncomms 13720

34. Broz ML, Binnewies M, Boldajipour B, Nelson AE, Pollack, JL, Erle DJ, et al. Dissecting the tumor myeloid compartment reveals rare activating antigenpresenting cells critical for $\mathrm{T}$ cell immunity. Cancer Cell (2014) 26:638-52. doi: 10.1016/j.ccell.2014.09.007

35. Tel J, Aarntzen EH, Baba T, Schreibelt G, Schulte BM, Benitez-Ribas D, et al. Natural human plasmacytoid dendritic cells induce antigen-specific T-cell responses in melanoma patients. Cancer Res. (2013) 73:1063-75. doi: 10.1158/0008-5472.CAN-12-2583

36. Prue RL, Vari F, Radford KJ, Tong H, Hardy MY, D’Rozario R, et al. A phase I clinical trial of CD1c (BDCA-1)+ dendritic cells pulsed with HLA-A*0201 peptides for immunotherapy of metastatic hormone refractory prostate cancer. J Immunother. (2015) 38:71-6. doi: 10.1097/CJI.00000000000 00063

37. Zhou Y, Bosch ML, Salgaller ML. Current methods for loading dendritic cells with tumor antigen for the induction of antitumor immunity. J Immunother. (2002) 25:289-303. doi: 10.1097/00002371-20020700000001

38. Neller MA, Lopez JA, Schmidt CW. Antigens for cancer immunotherapy. Semin Immunol. (2008) 20:286-95. doi: 10.1016/j.smim.2008. 09.006

39. Mitchell DA, Batich KA, Gunn MD, Huang MN, Sanchez-Perez L, Nair SK, et al. Tetanus toxoid and CCL3 improve dendritic cell vaccines in mice and glioblastoma patients. Nature (2015) 519:366-9. doi: 10.1038/nature 14320

40. Hou WS, Monem AR, Mossa MY, and Meselhy MR. Van Parijs L. A Bcl-2dependent molecular timer regulates the lifespan and immunogenicity of dendritic cells. Nat Immunol. (2004) 5:583-9. doi: 10.1038/ ni1071

41. Min S, Liang X, Zhang M, Zhang Y, Mei S, Liu J, et al. Multiple tumorassociated microRNAs modulate the survival and longevity of dendritic cells by targeting YWHAZ and Bcl2 signaling pathways. J Immunol. (2013) 190:2437-46. doi: 10.4049/jimmunol.1202282

42. Chen M, Huang L, Shabier Z, Wang J. Regulation of the lifespan in dendritic cell subsets. Mol Immunol. (2007) 44:2558-65. doi: 10.1016/j.molimm.2006.12.020

43. Kang TH, Lee JH, Noh KH, Han HD, Shin BC, Choi EY, et al. Enhancing dendritic cell vaccine potency by combining a BAK/BAX siRNA-mediated antiapoptotic strategy to prolong dendritic cell life with an intracellular strategy to target antigen to lysosomal compartments. Int J Cancer (2007) 120:1696-703. doi: 10.1002/ijc. 22377

44. Galluzzi L, Buque A, Kepp O, Zitvogel L, Kroemer G. Immunological effects of conventional chemotherapy and targeted anticancer agents. Cancer Cell (2015) 28:690-714. doi: 10.1016/j.ccell.2015. 10.012

45. Garg AD, Galluzzi L, Apetoh L, Baert T, Birge RB, Bravo-San Pedro JM, et al. Molecular and translational classifications of DAMPs in immunogenic 
cell death. Front Immunol. (2015) 6:588. doi: 10.3389/fimmu.2015. 00588

46. Galluzzi L, Buque A, Kepp O, Zitvogel L, Kroemer, G. Immunogenic cell death in cancer and infectious disease. Nat Rev Immunol. (2017) 17:97-111. doi: 10.1038/nri.2016.107

47. Zitvogel L, Apetoh L, Ghiringhelli F, Kroemer, G. Immunological aspects of cancer chemotherapy. Nat Rev Immunol. (2008) 8:59-73. doi: 10.1038/nri2216

48. Bracci L, Schiavoni G, Sistigu A, Belardelli, F. Immune-based mechanisms of cytotoxic chemotherapy: implications for the design of novel and rationalebased combined treatments against cancer. Cell Death Differ. (2014) 21:1525. doi: $10.1038 /$ cdd.2013.67

49. Karachi A, Dastmalchi F, Mitchell D, Rahman M. Temozolomide for immunomodulation in the treatment of glioblastoma. Neuro Oncol. (2018) 20:1566-72. doi: $10.1093 /$ neuonc/noy072

50. Beyranvand Nejad E, Welters MJ, Arens R, van der Burg SH. The importance of correctly timing cancer immunotherapy. Expert Opin Biol Ther (2017) 17:87-103. doi: 10.1080/14712598.2017.1256388

51. Veltman JD, Lambers ME, van Nimwegen M, de Jong S, Hendriks RW, Hoogsteden HC, et al. Low-dose cyclophosphamide synergizes with dendritic cell-based immunotherapy in antitumor activity. $J$ Biomed Biotechnol. (2010) 2010:798467. doi: 10.1155/2010/798467

52. Liu JY, Wu Y, Zhang XS, Yang JL, Li HL, Mao YQ, et al. Single administration of low dose cyclophosphamide augments the antitumor effect of dendritic cell vaccine. Cancer Immunol Immunother. (2007) 56:1597-604. doi: 10.1007/s00262-007-0305-4

53. Bauer C, Bauernfeind F, Sterzik A, Orban M, Schnurr M, Lehr HA, et al. Dendritic cell-based vaccination combined with gemcitabine increases survival in a murine pancreatic carcinoma model. Gut (2007) 56:1275-82. doi: 10.1136/gut.2006.108621

54. Ghansah T, Vohra N, Kinney K, Weber A, Kodumudi K, Springett G, et al. Dendritic cell immunotherapy combined with gemcitabine chemotherapy enhances survival in a murine model of pancreatic carcinoma. Cancer Immunol Immunother. (2013) 62:1083-91. doi: 10.1007/s00262-013-1 407-9

55. Carreno BM, Becker-Hapak M, Huang A, Chan M, Alyasiry A, Lie WR, et al. IL-12p70-producing patient DC vaccine elicits Tc1-polarized immunity. $J$ Clin Invest. (2013) 123:3383-94. doi: 10.1172/JCI68395

56. Cornelissen R, Hegmans JP, Maat AP, Kaijen-Lambers ME, Bezemer K, Hendriks RW, et al. Extended tumor control after dendritic cell vaccination with low-dose cyclophosphamide as adjuvant treatment in patients with malignant pleural mesothelioma. Am J Respir Crit Care Med. (2016) 193:1023-31. doi: 10.1164/rccm.201508-1573OC

57. Borch TH, Engell-Noerregaard L, Zeeberg Iversen T, Ellebaek E, Met Ö, Hansen M, et al. mRNA-transfected dendritic cell vaccine in combination with metronomic cyclophosphamide as treatment for patients with advanced malignant melanoma. Oncoimmunology (2016) 5:e1207842. doi: 10.1080/2162402X.2016.1207842

58. Tanyi JL, Bobisse S, Ophir E, Tuyaerts S, Roberti A, Genolet R, et al. Personalized cancer vaccine effectively mobilizes antitumor $T$ cell immunity in ovarian cancer. Sci Transl Med. (2018) 10:eaao5931. doi: 10.1126/scitranslmed.aao5931

59. Holtl L, Ramoner R, Zelle-Rieser C, Gander H, Putz T, Papesh C, et al. Allogeneic dendritic cell vaccination against metastatic renal cell carcinoma with or without cyclophosphamide. Cancer Immunol Immunother. (2005) 54:663-70. doi: 10.1007/s00262-004-0629-2

60. Ridolfi L, Petrini M, Granato AM, Gentilcore G, Simeone E, Ascierto $\mathrm{PA}$, et al. Low-dose temozolomide before dendritic-cell vaccination reduces (specifically) $\mathrm{CD} 4+\mathrm{CD} 25++$ Foxp3 + regulatory T-cells in advanced melanoma patients. J Transl Med. (2013) 11:135. doi: 10.1186/1479-5876-11-135

61. Akasaki Y, Kikuchi T, Homma S, Koido S, Ohkusa T, Tasaki T, et al. Phase I/II trial of combination of temozolomide chemotherapy and immunotherapy with fusions of dendritic and glioma cells in patients with glioblastoma. Cancer Immunol Immunother. (2016) 65:1499-509. doi: 10.1007/s00262-016-1905-7

62. Hunn MK, Bauer E, Wood CE, Gasser O, Dzhelali M, Ancelet LR, et al. Dendritic cell vaccination combined with temozolomide retreatment: results of a phase I trial in patients with recurrent glioblastoma multiforme. $J$ Neurooncol. (2015) 121:319-29. doi: 10.1007/s11060-014-1635-7

63. Pellegatta S, Eoli M, Cuccarini V, Anghileri E, Pollo B, Pessina S, et al. Survival gain in glioblastoma patients treated with dendritic cell immunotherapy is associated with increased NK but not CD8(+) T cell activation in the presence of adjuvant temozolomide. Oncoimmunology (2018) 7:e1412901. doi: 10.1080/2162402X.2017.1412901

64. Koido S, Homma S, Okamoto M, Takakura K, Mori M, Yoshizaki $S$, et al. Treatment with chemotherapy and dendritic cells pulsed with multiple Wilms' tumor 1 (WT1)-specific MHC class I/II-restricted epitopes for pancreatic cancer. Clin Cancer Res. (2014) 20:4228-39. doi: 10.1158/1078-0432.CCR-14-0314

65. Hegmans JP, Veltman JD, Lambers ME, de Vries IJ, Figdor CG, Hendriks RW, et al. Consolidative dendritic cell-based immunotherapy elicits cytotoxicity against malignant mesothelioma. Am J Respir Crit Care Med. (2010) 181:1383-90. doi: 10.1164/rccm.200909-1465OC

66. Lesterhuis WJ, de Vries IJ, Aarntzen EA, de Boer A, Scharenborg NM, van de Rakt M, et al. (2010). A pilot study on the immunogenicity of dendritic cell vaccination during adjuvant oxaliplatin/capecitabine chemotherapy in colon cancer patients. BrJ Cancer 103:1415-1421. doi: 10.1038/sj.bjc.6605935

67. Zhao X, Ji CY, Liu GQ, Ma DX, Ding HF, Xu M, et al. Immunomodulatory effect of DC/CIK combined with chemotherapy in multiple myeloma and the clinical efficacy. Int J Clin Exp Pathol. (2015) 8:13146-55.

68. Rozera C, Cappellini GA, D’Agostino G, Santodonato L, Castiello L, Urbani F, et al. Intratumoral injection of IFN-alpha dendritic cells after dacarbazine activates anti-tumor immunity: results from a phase I trial in advanced melanoma. J Transl Med. (2015) 13:139. doi: 10.1186/s12967-015-0473-5

69. Fukuda K, Funakoshi T, Sakurai T, Nakamura Y, Mori M, Tanese K, et al. Peptide-pulsed dendritic cell vaccine in combination with carboplatin and paclitaxel chemotherapy for stage IV melanoma. Melanoma Res. (2017) 27:326-34. doi: 10.1097/CMR.0000000000000342

70. Kongsted P, Borch TH, Ellebaek E, Iversen TZ, Andersen R, Met Ö, et al. Dendritic cell vaccination in combination with docetaxel for patients with metastatic castration-resistant prostate cancer: a randomized phase II study. Cytotherapy (2017) 19:500-13. doi: 10.1016/j.jcyt.2017.01.007

71. Matsuda T, Takeuchi H, Sakurai T, Mayanagi S, Booka E, Fujita T, et al. Pilot study of WT1 peptide-pulsed dendritic cell vaccination with docetaxel in esophageal cancer. Oncol Lett. (2018) 16:1348-56. doi: 10.3892/ol.2018.8734

72. Emadi A, Jones RJ, Brodsky RA. Cyclophosphamide and cancer: golden anniversary. Nat Rev Clin Oncol. (2009) 6:638-47. doi: 10.1038/nrclinonc.2009.146

73. Dréan A, Goldwirt L, Verreault M, Canney M, Schmitt C, Guehennec J, et al. Blood-brain barrier, cytotoxic chemotherapies and glioblastoma. Expert Rev Neurother. (2016) 16:1285-300. doi: 10.1080/14737175.2016.1202761

74. Quirt I, Verma S, Petrella T, and Bak K, Charette M. Temozolomide for the treatment of metastatic melanoma: a systematic review. Oncologist (2007) 12:1114-23. doi: 10.1634/theoncologist.12-9-1114

75. Kershaw MH, Devaud C, John LB, Westwood JA, Darcy PK. Enhancing immunotherapy using chemotherapy and radiation to modify the tumor microenvironment. Oncoimmunology (2013) 2:e25962. doi: $10.4161 /$ onci.25962

76. Demaria S, Formenti SC. Role of T lymphocytes in tumor response to radiotherapy. Front Oncol. (2012) 2:95. doi: 10.3389/fonc.2012.00095

77. Bhattacharyya T, Purushothaman K, Puthiyottil SS, Bhattacharjee A, Muttah G. Immunological interactions in radiotherapy-opening a new window of opportunity. Ann Transl Med. (2016) 4:51. doi: 10.3978/j.issn.2305-5839.2015.10.44

78. Brix N, Tiefenthaller A, Anders H, Belka C, Lauber, K. Abscopal, immunological effects of radiotherapy: Narrowing the gap between clinical and preclinical experiences. Immunol Rev. (2017) 280:249-79. doi: $10.1111 /$ imr. 12573

79. Teitz-Tennenbaum S, Li Q, Okuyama R, Davis MA, Sun R, Whitfield $\mathrm{J}$, et al. Mechanisms involved in radiation enhancement of intratumoral dendritic cell therapy. J Immunother. (2008) 31:345-58. doi: 10.1097/CJI.0b013e318163628c

80. de la Cruz-Merino L, Illescas-Vacas A, Grueso-López A, Barco-Sánchez A, Míguez-Sánchez C, Cancer Immunotherapies Spanish Group (GETICA) Radiation for awakening the dormant immune system, a 
promising challenge to be explored. Front Immunol. (2014). 5:102. doi: 10.3389/fimmu.2014.00102

81. Golden EB, Chhabra A, Chachoua A, Adams S, Donach M, FentonKerimian M, et al. Local radiotherapy and granulocyte-macrophage colonystimulating factor to generate abscopal responses in patients with metastatic solid tumours: a proof-of-principle trial. Lancet Oncol. (2015) 16:795-803. doi: 10.1016/S1470-2045(15)00054-6

82. Chakravarty PK, Alfieri A, Thomas EK, Beri V, Tanaka KE, Vikram B, et al. Flt3-ligand administration after radiation therapy prolongs survival in a murine model of metastatic lung cancer. Cancer Res. (1999) 59:6028-32.

83. Akutsu Y, Matsubara H, Urashima T, Komatsu A, Sakata H, Nishimori $\mathrm{T}$, et al. Combination of direct intratumoral administration of dendritic cells and irradiation induces strong systemic antitumor effect mediated by GRP94/gp96 against squamous cell carcinoma in mice. Int J Oncol. (2007) 31:509-15. doi: 10.3892/ijo.31.3.509

84. Teitz-Tennenbaum S, Li Q, Rynkiewicz S, Ito F, Davis MA, McGinn CJ, et al. Radiotherapy potentiates the therapeutic efficacy of intratumoral dendritic cell administration. Cancer Res. (2003) 63:8466-75.

85. Huang J, Wang Y, Guo J, Lu H, Lin X, Ma L, et al. Radiation-induced apoptosis along with local and systemic cytokine elaboration is associated with DC plus radiotherapy-mediated renal cell tumor regression. Clin Immunol. (2007) 123:298-310. doi: 10.1016/j.clim.2007.02.005

86. Teitz-Tennenbaum S, Li Q, Davis MA, Wilder-Romans K, Hoff J, Li M, et al. Radiotherapy combined with intratumoral dendritic cell vaccination enhances the therapeutic efficacy of adoptive T-cell transfer. J Immunother. (2009) 32:602-12. doi: 10.1097/CJI.0b013e3181a95165

87. Lee TH, Cho YH, Lee JD, Yang WI, Shin JL, Lee MG. Enhanced antitumor effect of dendritic cell based immunotherapy after intratumoral injection of radionuclide Ho-166 against B16 melanoma. Immunol Lett. (2006) 106:1926. doi: 10.1016/j.imlet.2006.03.007

88. Tatsuta K, Tanaka S, Tajiri T, Shibata S, Komaru A, Ueda Y, et al. Complete elimination of established neuroblastoma by synergistic action of gammairradiation and DCs treated with $\mathrm{rSeV}$ expressing interferon-beta gene. Gene Ther. (2009) 16:240-51. doi: 10.1038/gt.2008.161

89. Chi KH, Liu SJ, Li CP, Kuo HP, Wang YS, Chao Y, et al. Combination of conformal radiotherapy and intratumoral injection of adoptive dendritic cell immunotherapy in refractory hepatoma. J Immunother. (2005) 28:129-35. doi: 10.1097/01.cji.0000154248.74383.5e

90. Finkelstein SE, Iclozan C, Bui MM, Cotter MJ, Ramakrishnan R, Ahmed J, et al. Combination of external beam radiotherapy (EBRT) with intratumoral injection of dendritic cells as neo-adjuvant treatment of high-risk soft tissue sarcoma patients. Int J Radiat Oncol Biol Phys. (2012) 82:924-32. doi: 10.1016/j.ijrobp.2010.12.068

91. Lugade AA, Moran JP, Gerber SA, Rose RC, Frelinger JG, Lord EM. Local radiation therapy of B16 melanoma tumors increases the generation of tumor antigen-specific effector cells that traffic to the tumor. J Immunol. (2005) 174:7516-23. doi: 10.4049/jimmunol.174.12.7516

92. Lugade AA, Sorensen EW, Gerber SA, Moran JP, Frelinger JG, Lord EM. Radiation-induced IFN-gamma production within the tumor microenvironment influences antitumor immunity. J Immunol. (2008) 180:3132-9. doi: 10.4049/jimmunol.180. 5.3132

93. Chakraborty M, Abrams SI, Camphausen K, Liu K, Scott T, Coleman CN, et al. Irradiation of tumor cells up-regulates Fas and enhances CTL lytic activity and CTL adoptive immunotherapy. J Immunol. (2003) 170:6338-47. doi: 10.4049/jimmunol.170.12.6338

94. Reits EA, Hodge JW, Herberts CA, Groothuis TA, Chakraborty M, Wansley $\mathrm{EK}$, et al. Radiation modulates the peptide repertoire, enhances MHC class I expression, and induces successful antitumor immunotherapy. J Exp Med. (2006) 203:1259-71. doi: 10.1084/jem.20052494

95. Matsumura S, Wang B, Kawashima N, Braunstein S, Badura M, Cameron TO, et al. Radiation-induced CXCL16 release by breast cancer cells attracts effector T cells. J Immunol. (2008) 181:3099-107. doi: 10.4049/jimmunol.181.5.3099

96. Kim JY, Son YO, Park SW, Bae JH, Chung JS, Kim HH, et al. Increase of NKG2D ligands and sensitivity to NK cell-mediated cytotoxicity of tumor cells by heat shock and ionizing radiation. Exp Mol Med. (2006) 38:474-84. doi: $10.1038 / \mathrm{emm} .2006 .56$
97. Wang $\mathrm{C}, \mathrm{Pu}$ J, Yu H, Liu Y, Yan $\mathrm{H}, \mathrm{He} \mathrm{Z}$, et al. A dendritic cell vaccine combined with radiotherapy activates the specific immune response in patients with esophageal cancer. J Immunother. (2017) 40:71-6. doi: 10.1097/CJI.0000000000000155

98. Zhang L, Xu Y, Shen J, He F, Zhang D, Chen Z, et al. Feasibility study of DCs/CIKs combined with thoracic radiotherapy for patients with locally advanced or metastatic non-small-cell lung cancer. Radiat Oncol. (2016) 11:60. doi: 10.1186/s13014-016-0635-5

99. Leach DR, Krummel MF, Allison JP. Enhancement of antitumor immunity by CTLA-4 blockade. Science (1996) 271:1734-6. doi: 10.1126/science.271.5256.1734

100. Hirano F, Kaneko K, Tamura H, Dong H, Wang S, Ichikawa M, et al. Blockade of $\mathrm{B} 7-\mathrm{H} 1$ and $\mathrm{PD}-1$ by monoclonal antibodies potentiates cancer therapeutic immunity. Cancer Res. (2005) 65:1089-96.

101. Baumeister SH, Freeman GJ, Dranoff G, Sharpe AH. Coinhibitory Pathways in Immunotherapy for Cancer. Annu Rev Immunol. (2016) 34:539-73. doi: 10.1146/annurev-immunol-032414-112049

102. Zarour HM. Reversing T-cell dysfunction and exhaustion in cancer. Clin Cancer Res. (2016) 22:1856-64. doi: 10.1158/1078-0432.CCR-15-1849

103. Liu Y, Cheng Y, Xu Y, Wang Z, Du X, Li C, et al. Increased expression of programmed cell death protein 1 on NK cells inhibits NK-cell-mediated antitumor function and indicates poor prognosis in digestive cancers. Oncogene (2017) 36:6143-53. doi: 10.1038/onc.2017.209

104. Bardhan K, Anagnostou T, Boussiotis VA. The PD1:PD-L1/2 pathway from discovery to clinical implementation. Front Immunol. (2016) 7:550. doi: $10.3389 /$ fimmu.2016.00550

105. Gato-Cañas M, Zuazo M, Arasanz H, Ibañez-Vea M, Lorenzo L, FernandezHinojal G, et al. PDL1 signals through conserved sequence motifs to overcome interferon-mediated cytotoxicity. Cell Rep. (2017) 20:1818-29. doi: 10.1016/j.celrep.2017.07.075

106. Rosenblatt J, Glotzbecker B, Mills H, Vasir B, Tzachanis D, Levine JD, et al. PD-1 blockade by CT-011, anti-PD-1 antibody, enhances ex vivo T-cell responses to autologous dendritic cell/myeloma fusion vaccine. $J$ Immunother. (2011) 34:409-18. doi: 10.1097/CJI.0b013e31821ca6ce

107. Nagaoka K, Hosoi A, Iino T, Morishita Y, Matsushita H, Kakimi K. Dendritic cell vaccine induces antigen-specific $\mathrm{CD} 8(+) \mathrm{T}$ cells that are metabolically distinct from those of peptide vaccine and is well-combined with PD-1 checkpoint blockade. Oncoimmunology (2018) 7:e1395124. doi: 10.1080/2162402X.2017.1395124

108. Antonios JP, Soto H, Everson RG, Orpilla J, Moughon D, Shin N, et al. PD-1 blockade enhances the vaccination-induced immune response in glioma. JCI Insight (2016) 1:e87059. doi: 10.1172/jci.insight.87059

109. Ge Y, Xi H, Ju S, Zhang, X. Blockade of PD-1/PD-L1 immune checkpoint during DC vaccination induces potent protective immunity against breast cancer in hu-SCID mice. Cancer Lett. (2013) 336:253-259. doi: 10.1016/j.canlet.2013.03.010

110. Curiel TJ, Wei S, Dong H, Alvarez X, Cheng P, Mottram P, et al. Blockade of B7-H1 improves myeloid dendritic cell-mediated antitumor immunity. Nat Med. (2003) 9:562-7. doi: 10.1038/nm863

111. Ge W, Ma X, Li X, Wang Y, Li C, Meng H, et al. B7-H1 up-regulation on dendritic-like leukemia cells suppresses $\mathrm{T}$ cell immune function through modulation of IL-10/IL-12 production and generation of Treg cells. Leuk Res (2009) 33:948-57. doi: 10.1016/j.leukres.2009.01.007

112. Gibbons RM, Liu X, Harrington SM, Krco CJ, Kwon ED, Dong H. B7$\mathrm{H} 1$ signaling is integrated during $\mathrm{CD} 8(+) \mathrm{T}$ cell priming and restrains effector differentiation. Cancer Immunol Immunother. (2014) 63:859-67. doi: 10.1007/s00262-014-1563-6

113. Sponaas AM, Moharrami NN, Feyzi E, Standal T, Holth Rustad E, Waage A, et al., (2015). PDL1 expression on plasma and dendritic cells in myeloma bone marrow suggests benefit of targeted anti PD1-PDL1 therapy. PLoS ONE 10:e0139867. doi: 10.1371/journal.pone.0139867

114. Pulko V, Liu X, Krco CJ, Harris KJ, Frigola X, Kwon ED, et al. TLR3-stimulated dendritic cells up-regulate B7-H1 expression and influence the magnitude of CD8 T cell responses to tumor vaccination. J Immunol. (2009) 183:3634-41. doi: 10.4049/jimmunol.09 00974

115. Schneider T, Hoffmann H, Dienemann H, Schnabel PA, Enk AH, Ring S, et al. Non-small cell lung cancer induces an immunosuppressive phenotype of 
dendritic cells in tumor microenvironment by upregulating B7-H3. J Thorac Oncol. (2011) 6:1162-8. doi: 10.1097/JTO.0b013e31821c421d

116. Song S, Yuan P, Wu H, Chen J, Fu J, Li P, et al. Dendritic cells with an increased PD-L1 by TGF-beta induce T cell anergy for the cytotoxicity of hepatocellular carcinoma cells. Int Immunopharmacol. (2014) 20:117-23. doi: 10.1016/j.intimp.2014.02.027

117. Francisco LM, Salinas VH, Brown KE, Vanguri VK, Freeman GJ, Kuchroo VK, et al. PD-L1 regulates the development, maintenance, and function of induced regulatory T cells. J Exp Med. (2009) 206:3015-29. doi: 10.1084/jem.20090847

118. Park SJ, Namkoong H, Doh J, Choi JC, Yang BG, Park Y, et al. Negative role of inducible PD-1 on survival of activated dendritic cells. J Leukoc Biol. (2014) 95:621-9. doi: 10.1189/jlb.0813443

119. Wang S, Wang Y, Liu J, Shao S, Li X, Gao J, et al. Silencing B7-H1 enhances the anti-tumor effect of bladder cancer antigen-loaded dendritic cell vaccine in vitro. Onco Targets Ther. (2014) 7:1389-96. doi: 10.2147/OTT.S65367

120. Van den Bergh JMJ, Smits ELJM, Berneman ZN, Hutten TJA, De Reu $\mathrm{H}$, Van Tendeloo VFI, et al. Monocyte-derived dendritic cells with silenced PD-1 ligands and transpresenting interleukin-15 stimulate strong tumor-reactive T-cell expansion. Cancer Immunol Res. (2017) 5:710-5. doi: 10.1158/2326-6066.CIR-16-0336

121. Hobo W, Novobrantseva TI, Fredrix H, Wong J, Milstein S, Epstein-Barash $\mathrm{H}$, et al. Improving dendritic cell vaccine immunogenicity by silencing PD-1 ligands using siRNA-lipid nanoparticles combined with antigen mRNA electroporation. Cancer Immunol Immunother. (2013) 62:285-97. doi: 10.1007/s00262-012-1334-1

122. Daneshmandi S, Pourfathollah AA, Karimi MH, Emadi-Baygi M. PDL-1/PDL-2 blockade in mice dendritic cells by RNAi techniques to induce antitumor immunity. Immunotherapy (2015)7:1145-58. doi: $10.2217 / \mathrm{imt} .15 .80$

123. Roeven MW, Hobo W, van der Voort R, Fredrix H, Norde WJ, Teijgeler K, et al. Efficient nontoxic delivery of PD-L1 and PD-L2 siRNA into dendritic cell vaccines using the cationic lipid SAINT-18. J Immunother. (2015) 38:145-54. doi: 10.1097/CJI.0000000000000071

124. Chambers CA, Kuhns MS, Egen JG, Allison JP. CTLA-4-mediated inhibition in regulation of $\mathrm{T}$ cell responses: mechanisms and manipulation in tumor immunotherapy. Annu Rev Immunol. (2001) 19:565-94. doi: 10.1146/annurev.immunol.19.1.565

125. Blank CU, Zhao X, Yue GX, Wang ZF, Enk A. Therapeutic use of anti-CTLA4 antibodies. Int Immunol. (2015) 27:3-10. doi: 10.1093/intimm/dxu076

126. Romano E, Kusio-Kobialka M, Foukas PG, Baumgaertner P, Meyer C, Ballabeni $\mathrm{P}$, et al. Ipilimumab-dependent cell-mediated cytotoxicity of regulatory $\mathrm{T}$ cells ex vivo by nonclassical monocytes in melanoma patients. Proc Natl Acad Sci USA. (2015) 112:6140-5. doi: 10.1073/pnas.1417320112

127. Ramagopal UA, Liu W, Garrett-Thomson SC, Bonanno JB, Yan Q, Srinivasan $\mathrm{M}$, et al. Structural basis for cancer immunotherapy by the first-inclass checkpoint inhibitor ipilimumab. Proc Natl Acad Sci USA. (2017) 114:E4223-32. doi: 10.1073/pnas.1617941114

128. Sharma A, Subudhi SK, Blando J, Scutti J, Vence L, Wargo JA, et al. Anti-CTLA-4 immunotherapy does not deplete FOXP3+ regulatory T cells (Tregs) in human cancers. Clin Cancer Res. (2018) doi: 10.1158/1078-0432.CCR-18-0762. [Epub ahead of print].

129. Boudewijns S, Koornstra RH, Westdorp H, Schreibelt G, van den Eertwegh AJ, Geukes Foppen MH, et al. Ipilimumab administered to metastatic melanoma patients who progressed after dendritic cell vaccination. Oncoimmunology (2016) 5:e1201625. doi: 10.1080/2162402X.2016.1201625

130. Ribas A, Comin-Anduix B, Chmielowski B, Jalil J, de la Rocha P, McCannel TA, et al. Dendritic cell vaccination combined with CTLA4 blockade in patients with metastatic melanoma. Clin Cancer Res. (2009)15:6267-76. doi: 10.1158/1078-0432.CCR-09-1254

131. Wilgenhof S, Corthals J, Heirman C, van Baren N, Lucas S, Kvistborg P, et al Phase II study of autologous monocyte-derived mrna electroporated dendritic cells (TriMixDC-MEL) plus ipilimumab in patients with pretreated advanced melanoma. J Clin Oncol. (2016) 34:1330-8. doi: 10.1200/JCO.2015.63.4121

132. Dammeijer F, Lievense LA, Kaijen-Lambers ME, van Nimwegen M, Bezemer K, Hegmans JP, et al. Depletion of tumor-associated macrophages with a CSF-1R kinase inhibitor enhances antitumor immunity and survival induced by DC immunotherapy. Cancer Immunol Res. (2017) 5:535-46. doi: 10.1158/2326-6066.CIR-16-0309

133. Lievense L, Dammeijer F, Lambers-Kaijen M, Hendriks R, Van Nimwegen M, Hegmans J, et al. Combination therapy with a CD40-agonist and dendritic cell immunotherapy has synergistic effects in a murine mesothelioma model. J Thor Oncol. (2015) 10:S253.

134. Prasad SJ, Farrand KJ, Matthews SA, Chang JH, McHugh RS, Ronchese F. Dendritic cells loaded with stressed tumor cells elicit long-lasting protective tumor immunity in mice depleted of $\mathrm{CD} 4+\mathrm{CD} 25+$ regulatory T cells. J Immunol. (2005) 174:90-8. doi: 10.4049/jimmunol.17 4.1 .90

Conflict of Interest Statement: JA: No relationship to disclose in relation to the submitted work. Relevant financial activities outside the submitted work: Stock or Other Ownership: Amphera Consulting or Advisory Role: Bristol-Myers Squibb, MSD Oncology, Boehringer Ingelheim, Eli-Lilly, Roche Speakers Bureau: AstraZeneca. Research Funding: Genentech (Inst), Boehirnger Ingelheim (inst). Patents, Royalties, Other Intellectual Property: Patent: Tumor cell lysate for dendritic cell loading (Inst), SNP analyses for immunotherapy (Inst).

The remaining authors declare that the research was conducted in the absence of any commercial or financial relationships that could be construed as a potential conflict of interest.

Copyright (๑) 2018 van Gulijk, Dammeijer, Aerts and Vroman. This is an open-access article distributed under the terms of the Creative Commons Attribution License (CC $B Y)$. The use, distribution or reproduction in other forums is permitted, provided the original author(s) and the copyright owner(s) are credited and that the original publication in this journal is cited, in accordance with accepted academic practice. No use, distribution or reproduction is permitted which does not comply with these terms. 